\title{
ADVANCEMENTS IN MESENCHYMAL STEM CELL TREATMENT FOR BUERGER'S DISEASE
}

\section{NAPREDAK U TERAPIJI BIRGEROVE BOLESTI MEZENHIMALNIM STEM ĆELIJAMA}

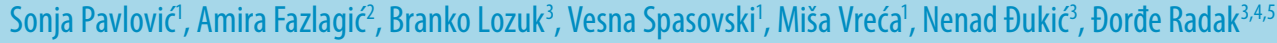

\section{Summary}

Buerger's disease or thromboangiitis obliterans, is a non-atherosclerotic inflammatory process which mostly involves medium and small sized arteries and veins in lower and upper extremities. It is categorized as vasculitis. The disease is known to be closely linked to smoking. Buerger's disease is a long-term debilitating condition because of the pain, the development of ulcers and gangrene, and the risk of amputation.

Drugs effective on erythrocyte flexibility, agents acting on platelets, non-steroidal anti-inflammatory drugs and vascular reconstruction are among several therapeutic methods for Buerger's disease. However, the applied therapies are insufficiently effective. Still, the base of treatment is smoking cessation. Lately, cell therapy has offered us entirely new possibilities.

Mesenchymal stem cell (MSC) treatment has been proposed as a novel approach for tissue engineering and regenerative medicine for various ischemic disorders, including Buerger's disease. In 2016, the first MSC- based therapy has received regulatory approval for the treatment of Buerger's disease in India. In March 2017, orphan designation was granted by the European Commission for autologous adipose tissue-derived MSC for the treatment of Buerger's disease. Novel therapeutic approach needs to be validated in the upcoming studies conducted in different clinical centers.

Key words: Buerger's disease, mesenchymal stem cells, orphan drug

\section{Sažetak}

Birgerova bolest (thromboangiitis obliterans) je neaterosklerotski inflamatorni proces koji uglavnom zahvata male i srednje arterije i vene u donjim i gornjim udovima. Okarakterisan je kao vrsta vaskulitisa. Nastanak, napredovanje i težina bolesti su povezani sa pušenjem. Birgerovu bolest karakterišu bol, pojava ishemičnih ulkusa, gangrena i rizik od amputacije, što značajno utiče na kvalitet života pacijenta.

Trombolitička terapija, primena nesteroidnih antiinflamatornih lekova i vaskularno-hirurški rekonstruktivni zahvati su neki od terapijskih pristupa u lečenju Birgerove bolesti. Međutim, ovi načini lečenja nisu dovoljno efikasni. Još uvek najbolji efekat na poboljšanje bolesti ima prekid pušenja. U poslednje vreme, ćelijska terapija je ponudila sasvim nove mogućnosti lečenju Birgerove bolesti.

Terapija mezenhimskim matičnim ćelijama (MMĆ) je prepoznata kao novi pristup u tkivnom inženjerstvu i regenerativnoj medicini, primenljiv u lečenju različitih ishemijski poremećaja, uključujući Birgerovu bolest. Prva terapija koja koristi MMĆ u lečenju Birgerove bolesti je odobrena u Indiji 2016. godine. U martu 2017. godine Evropska komisija je terapiju autolognim MMĆ iz adipoznog tkiva uvrstila u lekove „siročice" za Birgerovu bolest. Ovaj novi terapijski pristup je neophodno validirati u narednim studijama u više kliničkih centara.

Ključne reči: Birgerova bolest, mezenhimske matične ćelije, lek „siročićc

\section{INTRODUCTION}

Thromboangiitis obliterans (TAO), also known as Buerger's disease, is a nonatherosclerotic process that most commonly affects the small and medium-sized arteries and veins in the upper and lower extremities. TAO was first described in 1879, when two Austrian surgeons, Felix von Winiwarter and Theodor Billroth, reported in the German Archives of Clinical Surgery a single case of what they described as "presenile spontaneous gangrene" (1). Almost half a century later, in 1924. Buerger described in detail the absence of large vessel involvement as opposed to what was thought by Winiwarter and Billroth, linking this disease with smoking, thus determining tobacco use as a predisposing factor and naming this condition thromboangiitis obliterans (2), (Figure 1, Figure 2).

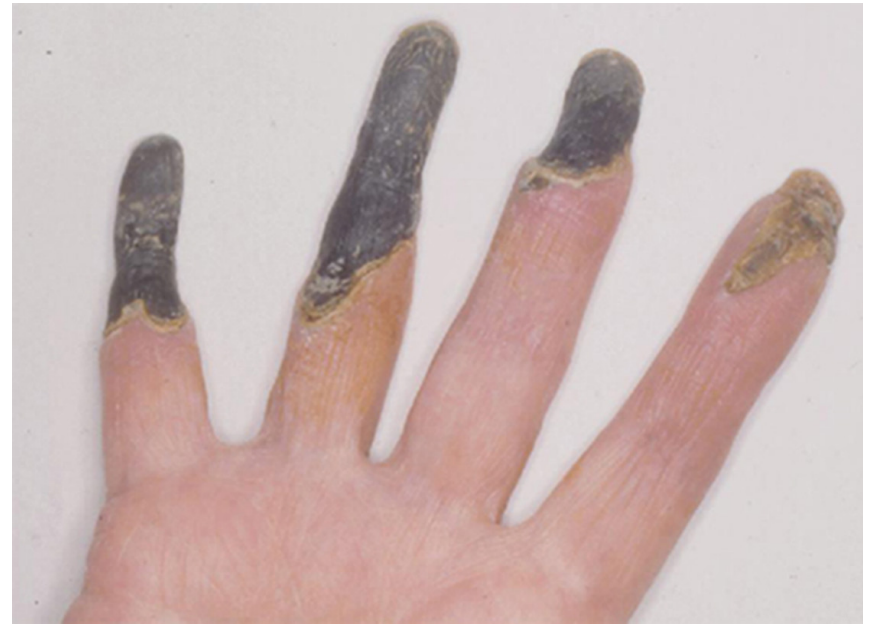

Figure 1. Trombangitis obliterans in progress 


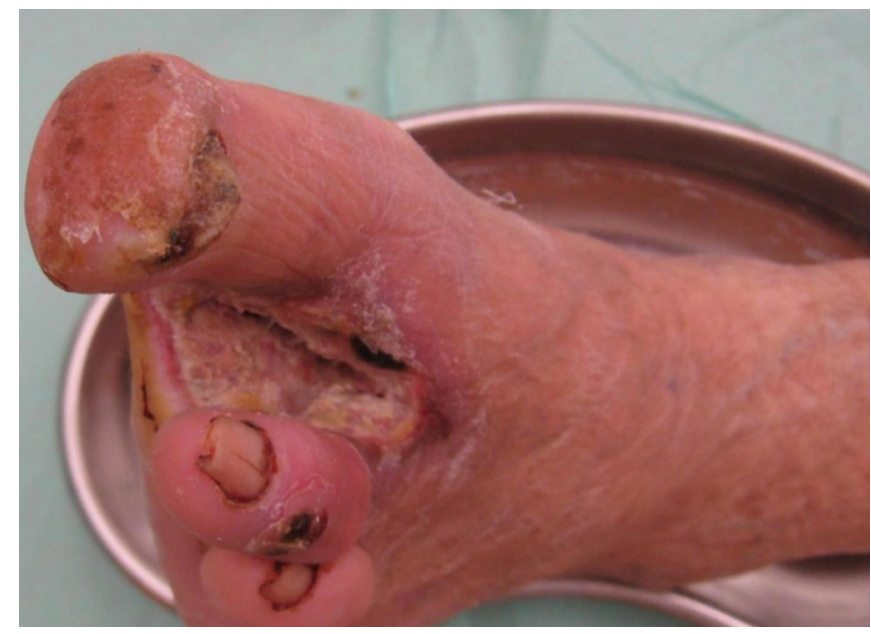

Figure 2. Thrombangitis obliteralis in progress

\section{EPIDEMIOLOGY}

TAO is a rare disease, since it affects approximately 1 in 10.000 people in the European Union (EU). This is equivalent to a total of around 52.000 people. Today it is proven that this disease is closely associated with smoking and that it mostly affects male patients aged 25 to 40. The ratio is 3 to 1 in favor of men. With a significant decrease in the number of smokers in the world, consequently the prevalence of this disease has been reduced as well. In Europe, it is from 0.5 up to $5.3 \%$, while high values of over $60 \%$ are still found in India and Pakistan. The greatest number of patients has been recorded among Jews of Ashkenazi ancestry living in Israel with prevalence of up to $80 \%$. $(3,4)$

\section{Etiology And Pathogenesis}

The etiology of Buerger's disease is still unknown, despite a great progress in medicine. The fact is that although $\mathrm{TAO}$ is a type of vasculitis, it differs from other forms of vasculitis, due to much less intense cellular activity in the wall of the blood vessel. Immunologic markers, such as erythrocyte sedimentation rate (ESR) and C-reactive protein (CRP), rheumatoid factor and antinuclear antibody levels, are usually normal or slightly elevated, which is not the case in other types of vasculitis (4).

Tobacco use or exposure plays a central role in the initiation and progression of the disease. It is considered that the patients have a sort of nicotine hypersensitivity or allergy. Namely, it is believed that tobacco glycoprotein (TGP) could be related to changes in blood vessels and some works have proven that the development of Buerger's disease can be directly monitored by measuring the urine level of nicotine metabolite cotinine (5).

As for genetic predisposition, it has not yet been proven, although some studies have mentioned higher prevalence of allele histocompatibility complex HLA A9 A5 and B5 (6).
Many have tried to prove the importance of hypercoagulability in connection to the development of this disease. Although it has not yet been definitively verified, some studies have shown that patients with TAO, who have elevated level of homocysteine, may also have a higher amputation rate than those with normal homocysteine levels $(5,6)$.

Immunological aspects of this disease are highly important since one of the explanations for this disease is that it is an autoimmune disorder with antibodies directed towards vascular endothelium in response to antigens in tobacco. The presence of different antibodies, such as antinuclear, antielastin, anticollagens I and III, and antinicotine antibodies, as well as identification of deposits of immunoglobulin (Ig) G, IgC3, and IgC4 in the blood vessels of patients, provided evidence to the theory of the immune character of the disease $(7,8)$.

\section{Histopathology}

Disease progress can be divided into three phases, acute, intermediate and chronic phase. In all stages of the disease, the normal architecture of the vessel wall, subjacent to the occlusive thrombus and including the internal elastic lamina remains essentially intact, which distinguishes this disease from all other types of vasculitis?

Acute-phase lesion is characterized by acute inflammation involving all coats of the vessel wall, especially of the veins, in association with occlusive thrombosis around which polymorphonuclears accumulate on periphery, creating micro abscesses. Progressive organization of the occlusive thrombus in the arteries and veins with the possibility of recanalization is found in intermediate phase, while the thrombus formation with fibrotic changes is a clear sign that the disease is in its end stage.

\section{Clinical Features}

Buerger's disease is frequent among men younger than 45 and smokers. One of early symptoms are leg claudications, the necessity for frequent resting, mild swelling in extremities and ischemic ulcers on the fingers and toes. A significant number of patients have superficial thrombophlebitis and paresthesia, while more than $80 \%$ of patients have changes on 3 to 4 extremities $(9,10,11)$.

\section{DiAgNosis}

Since there are neither analyses nor special diagnostic methods for determining this disease, it is highly important to perform comprehensive laboratory analyses 
in order to exclude other diseases (Table 1) and to take into consideration all differential diagnostic investigations in order to be positive that the patient is suffering from this disease (Table 2) $(12,13,14)$. Angiography is present with specific "corkscrew" sign. (Figure 3)

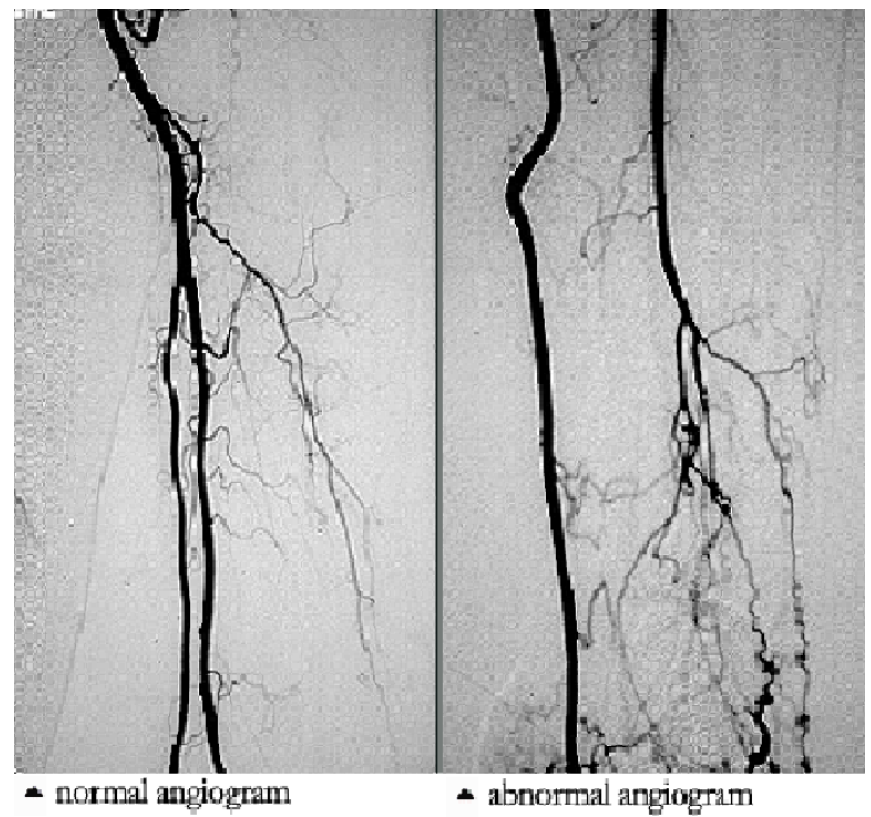

Figure 3. Normal and angiogram in TAO disease

Table 1. Diagnostic Investigations for Buerger's Disease

\begin{tabular}{l} 
Diagnostic Investigations for Buerger's Disease \\
Blood Count \\
Liver function \\
Renal function \\
Fasting blood sugar \\
Erythrocyte sedimentation rate \\
C-reactive protein \\
Antinuclear antibodies \\
Rheumatoid factor \\
Complement Measurements \\
Anticentromere antibodies (for CREST) \\
Anti-Scl-70 antibodies (for Scleroderma) \\
Antiphospholipid antibodies \\
Lipid profile \\
Urinalysis \\
Toxicologic screen for cocaine and cannabis \\
Cryoproteins \\
\hline Segmental Arterial Doppler Pressures \\
Arteriography \\
Echocardiography (to exclude source of emboli) \\
Computed tomography (to exclude potential source of emboli) \\
Biopsy (in proximal artedy involvement or unusual locations) \\
Complete thrombophilia screen: Protein C, S, Antithrombin III, \\
Factor V Leiden, Prothrombin 20210, and Homocysteinemia \\
\hline
\end{tabular}

CREST- Calcinosis, Raynaud's phenomenon, esophageal dysmotility, sclerodactyly, and telangiectasia. ${ }^{*}$ Adapted from (12)
Table 2. Diagnostic criteria for Buerger's Disease

\begin{tabular}{|c|c|}
\hline \multicolumn{2}{|l|}{ Diagnostic Criteria } \\
\hline Shionoya criteria (13) & Olin criteria (14) \\
\hline Onset before age 50 & Onset before age 45 \\
\hline Smoking history & Current (or recent past) tobacco use \\
\hline \multirow{2}{*}{$\begin{array}{l}\text { Infrapopliteal arterial } \\
\text { occlusions upper limb } \\
\text { involvement or phlebi- } \\
\text { tis migraines }\end{array}$} & $\begin{array}{l}\text { Distal extremity ischemia (infrapapli- } \\
\text { teal and/or intrabrachial), such as clau- } \\
\text { dication, rest pain, ischemic ulcers, and } \\
\text { gangrene documented with noninvasive } \\
\text { testing }\end{array}$ \\
\hline & $\begin{array}{l}\text { Laboratory tests to exclude autoimmune } \\
\text { or connective tissue diseases and diabe- } \\
\text { tes mellitus }\end{array}$ \\
\hline \multirow{2}{*}{$\begin{array}{l}\text { Absence of atheroscle- } \\
\text { rotic risk factors other } \\
\text { than smoking }\end{array}$} & $\begin{array}{l}\text { Exclude proximal source of emboli with } \\
\text { echocardiography and arteriography }\end{array}$ \\
\hline & $\begin{array}{l}\text { Demonstrate consistent arteriographic } \\
\text { findings in the involved and clinically } \\
\text { noninvolved limbs }\end{array}$ \\
\hline
\end{tabular}

Note: A biopsy is rarely needed to make the diagnosis, unless the patient presents with an unusual characteristic, such as large artery involvement or age greater than 45 years

\section{Treatment}

The most effective treatment for Buerger's disease is smoking cessation. In case the smoking continues, the chronic phase of this disease mostly ends with amputation. Nevertheless, the researches show that only 43 to $70 \%$ of patients succeed in giving up smoking, regardless the fact that stopping smoking means avoiding amputation (15).

Since we do not know its etiology, Buerger's disease therapy has changed over time, starting from platelet activity blocking, to vasodilatation, changing metabolism of the cells and up to nowadays application of cell therapy.

Acetylsalicylic acid (ASA) and Clopidogrel are used for platelet inhibition and are both successful in disease prevention, giving advantage to Clopidogrel use, due to its more powerful inhibition of platelet activity. Both medicines represent basic therapy and have no effect on decreasing symptoms or preventing disease progress for longer periods of time (15).

Vasodilator drugs have been used in attempt to improve blood flow proximal to lesion or occlusion. However, vasodilators have the capacity to reduce overall systemic vascular resistance, leading to a reduction in perfusion pressure and subsequently causing the ischemic insult in the hypoperfused extremity. Therefore, vasodilators are not suitable for TAO therapy.

Calcium channel blockers, such as nifedipine, amlodipine or verapamil are believed to provide more efficient oxygen utilization in diseased extremity (17).

Pentoxifylline is a medicine that prevents red blood cell deformability, decreases blood viscosity, platelet ad- 
hesiveness and secures reduction in fibrinogen levels. Though its usage may increase the pain-free walking distance in many, the long-term benefit and improvement in quality of life is limited (16).

Cilostazol is a phosphodiesterase type III inhibitor which inhibits cyclic adenosine monophosphate (cAMP) phosphodiesterase, thus decreasing platelet aggregation and providing muscle cell relaxation. Prolonged use of this medicine has numerous side effects such as headaches, of which patients need to be informed (18).

A few studies suggest surgical treatment that provides blood flow to a diseased extremity. The results have shown that this type of treatment is most successful in patients who have given up smoking $(17,18)$. Sympathectomy, performed by laparoscopic or open surgery method in order to decrease arterial spasm in patients with Buerger's disease, has not provided satisfactory results $(19,20,21,22)$.

Iloprost, a synthetic analogue of prostaglandin 12, acts through vasodilatation and effects platelets, preventing their granule release. Many studies have addressed treatments with prostaglandins and endothelin as a cure and possible decrease of amputation cases in patients with Buerger's disease, but without expected results $(23,24,25)$.

Seeking for alternative therapeutic approach, in the past decade cell therapy was introduced and it opened up entirely new chapter in Buerger's disease treatment.

\section{MESENCHYMAL STEM CELLS}

Mesenchymal stem cells (MSCs) are undifferentiated cells found in many organs and tissues of adult organisms, including humans. MSCs, like other stem cells, possess several features that make them special and different from other cell types in the body. The main feature of stem cells is their capacity for self-renewal, which enables that upon cell division at least one of daughter cells remains a stem cell. The decision of the cell fate, to move towards differentiation or to remain in the state of stemness, depends on the type of stem cell, microenvironment where it is situated and the needs of the tissue and the organism as a whole (26). MSCs have potency to differentiate into various cell types, meaning that they are able to become different cells of the specific tissue type. In addition, thanks to their plasticity, they are able, under specific in vitro conditions, to differentiate into cell types different from their origin. This means that stem cells of mesodermal origin are able to give cells of ectodermal or endodermal origin, and vice versa. $\mathrm{Hu}$ man MSCs (hMSCs) are the non-haematopoietic, multipotent stem cells with the capacity to differentiate into mesodermal lineage such as osteocytes, adipocytes and chondrocytes as well as ectodermal (neurocytes) and endodermal lineages (hepatocytes) (27). Furthermore, important characteristic of MSCs is homing, which is their ability to receive signals of specific tissue factors that are secreted in the place of injury or defect in the body? Attracted by these paracrine factors, they travel to that place and repair damaged tissue (28).

Mesenchymal stem cells possess all those features, and together with their low apoptotic potential and high proliferative rate, they have come in the focus of regenerative medicine. MSCs express immunoregulatory capacity, because they secrete large amounts of bioactive agents that inhibit T-cell recognition and expansion, as well as inhibition of maturation od B cells and other immune cell types (29). They also possess trophic effects, since they secrete a great number of cytokines and growth factors (30). Secretion of anti-inflammatory molecules makes MSCs an effective tool in the treatment of chronic conditions, like autoimmune, inflammatory and degenerative diseases $(31,32,33)$.

What makes MSCs especially attractive for regenerative medicine is the fact that they can be isolated from various tissues and in enormous number, using minimal invasive procedures. hMSCs for the first time were discovered in the bone marrow (34). Until now, they have been isolated from various tissues, including adipose tissue (35), amniotic fluid (36), endometrium (37), dental tissues (38), umbilical cord (39), Wharton's jelly (40) and many other tissues. Many studies compared MSCs form different sources, and although there are slight differences between them, these are not of such importance that would influence their regenerative capacity $(41,42)$. In the last decade, adipose tissue became especially attractive as a source of MSCs in terms of cell and tissue regeneration, for several reasons. Adipose tissue can be easily obtained using non -invasive procedures. A large number of MSCs can be harvested from adipose tissue. It was estimated that there are one hundred times more MSCs in the same amount of adipose tissue compared to bone marrow (43). They express cell surface markers defined for MSCs, like cluster of differentiation (CD) 29, CD44, CD73, CD90, $\mathrm{CD} 105$ and lack the expression of CD14, CD34, CD45 and HLA (human leucocyte antigen)-DR. Moreover, adipose tissue is available during whole lifespan, and its usage has few, if any, ethical issues. Many preclinical and clinical studies showed their benefits and safeness $(44,45,46)$.

\section{MSCS-BASED THERAPY FOR BUERGER'S DISEASE}

MSC treatment has been proposed as a novel approach for tissue engineering and regenerative medicine for various ischemic disorders, such as stroke, coronary artery disease, peripheral arterial disease (PAD) and critical limb ischemia (CLI), the most advanced clinical stage of peripheral arterial disease (47). 
The first reported human study using intramuscular administration of allogenic human umbilical cord-derived MSCs was conducted in four patients with Buerger's disease. Improved ulcer recovery time, enhanced limb perfusion, and relieved the symptoms of rest pain were observed (48). In the cohort of nine patients with Buerger's disease and three with diabetic foot ulcers, it has been shown that intramuscular administration of autologous bone marrow derived MSCs have accelerated ulcer healing and improved pain-free walking distance (49).

Lee et al (50) have demonstrated that autologous adipose tissue-derived MSCs treatment of patients with Buerger's disease and diabetic foot improved walking claudication distance, collateral vessel formation, wound healing, and clinical symptoms, especially pain relief.

Similar MSCs treatments have been successful in patients with systemic sclerosis (51) and diabetes mellitus $(52,53)$.

\section{Therapeutic PERSPECTIVES FOR BUERGER's DISEASE}

After completion of the phase $1 / 2$ clinical trial, using intramuscular administration of off the-shelf allogeneic bone marrow-derived MSCs into patients with critical limb ischemia (CLI), Stempeutics Research Pvt. Ltd. (Bangalore, India) has reported that the MSCs were well tolerated with no adverse events or rejection. A reduction in the number of ulcers was also demonstrated. No significant increase in amputation rate was observed. The efficacy of allogeneic bone marrow-derived MSCs has been assessed in phase $2 / 3$ clinical trials (54).

In 2016, the Stempeutics Research has received regulatory approval for 'limited marketing' of its product for the treatment of CLI due to Buerger's disease - the first stem cell based biologics to be approved by the Drugs Controller General of India (DCGI) (55). The product "stempeucel" - patented in the US, Japan, China and Malaysia - is derived from allogeneic pooled mesenchymal stromal cells, extracted from the bone marrow of adult voluntary donors. The goal of the Stempeutics Research is to complete the study on 200 patients and seek full marketing authorization by the end of 2017 .

Two phase 1 trials using intramuscular administration of allogeneic placenta-derived MSCs have been conducted by Pluristem Therapeutics Inc. (Haifa, Israel) since 2010. The study has demonstrated that these cells were safe with no adverse effects in patients with CLI and Buerger's disease. No specific anti-MSC HLA class I or II antibodies were detected. Only one out of 27 patients (3.7\%) had a major amputation within six months. This therapy significantly improved blood flow and quality of life and reduced pain score (56).
On 20 March 2017, orphan designation (EU/3/17/1854) was granted by the European Commission to SPC $\mathrm{GmbH}$, Germany, for autologous adipose tissue-derived mesenchymal stem cells (also known as VascoStem) for the treatment of Buerger's disease (57). The medicine is composed of MSCs that are extracted from the patient's own fat tissue. Taking patient's adipose tissue is a simple procedure, which can be done under local anesthesia, requiring only about $20 \mathrm{~g}$ of fat. After extraction, it is grown in laboratory to increase the number before being injected back into the patient. The effects of the MSCs have been evaluated in experimental models, and clinical trials in patients with Buerger's disease are ongoing. The number of people affected with Buerger's disease in $\mathrm{EU}$ is below the ceiling for orphan designation, which is 5 people in 10.000 . Besides the rarity of the condition to be treated, orphan medicinal product designations are based on additional criteria, such as: the seriousness of the condition, lack of alternative methods of diagnosis, prevention or treatment, insufficient returns on investment.

Designated orphan medicinal products are products that are still under investigation and are considered for orphan designation on the basis of potential activity. An orphan designation is not a marketing authorization. As a consequence, demonstration of quality, safety and efficacy is necessary before a product can be granted a marketing authorization. It is expected that treatment with this medicine will reduce damage to the blood vessels and so improve the symptoms of the Buerger's disease. Novel therapeutic approach needs to be validated in the studies conducted in different clinical centers.

\section{Conclusion}

TAO treatment has so far proved to have no long-term results. A group of patients, despite chronic therapy, is still facing the risk of limbs loss. Using the methods of implantation of MSCs, there is a possibility for establishing a process of angiogenesis, aiming to achieve significant long-term therapeutic improvement.

Although early results are promising, there is still a long path to cross from establishing a suitable production processes to imminent application of stem cells in targeted muscle groups. Nevertheless, the success of such treatment would allow patients with other vascular diseases to have hope and possibility to get significant correction in their clinical picture.

\section{ACKNOWLedgements}

This work is funded by the Ministry of Education, Science and Technological Development, Republic of Serbia (grant no. III 41004). 


\section{References}

1. Lie JT, Mann RJ, Ludwig J. The brothers von Winiwarter, Alexander (1848-1917) and Felix (1852-1931) and thromboangiitis obliterans. Mayo Clinic Proceedings 1979; 54 (12): 802-807

2. Buerger L. The Circulatory Disturbances of the Extremities. WB Saunders, Philadelphia, Pa, USA 1924

3. Cachovan M. Epidemiologic und geographisches Verteilungsmuster der Thromboangiitis obliterans in Thromboangiitis Obliterans Morbus Winiwarter-Buerger. Stuttgart HH, Ed., Germany Georg Thieme, 1988; 31-36

4. Mills JL, Taylor Jr, Porter JM. Buerger's disease in the modern era. American J of Surg. 1987; 154 (1): 123-129

5. Caramaschi P, Biasi D, Carletto A et al. Three cases of Buerger's disease associated with hyperhomocysteinemia. Clinic Exp Rheumatol. 2000; 18 (2): 264-265

6. Olin JW, Childs MB, Bartholomew JR et al. Anticardiolipin antibodies and homocysteine levels in patients with thromboangiitis obliterans. Arth Rheum. 1996; 39 (9): 47

7. Roncon de Albuquerque R, Delgado L, Correia P, Torrinha JF, Serrao D, Braga A. Circulating immune complexes in Buerger's disease. Endarteritis obliterans in young men. J Cardiovasc Surg. 1989; 30 (5): 821-825

8. Maslowski L, McBane R, Alexewicz P, Wysokinski WE. Antiphospholipid antibodies in thromboangiitis obliterans. Vascular Medicine 2002; 7 (4): 259-264

9. Shionoya S. Buerger's disease (thromboangiitis obliterans) in Vascular Surgery. Rutherford RB, Ed., WB Saunders, Philadelphia, Pa, USA 1989; 3: 207-217.

10. Barlas S, Elmaci T, Dayioğlu E et al. Has the clinical definition of thromboangiitis obliterans changed indeed?. Int J Angiol. 1997; 6 (1): 49-55

11. Juergens JL. Thromboangiitis obliterans, (Buerger's disease, TAO) in Peripheral Vascular Diseases. Juergens JL,. Spittel JA, Fairbairn JF, Eds., WB Saunders, Philadelphia, Pa, USA 1980: 469-491

12. Lazarides MK, Georgiadis GS. Papas TT, Nikolopoulos ES. Diagnostic criteria and treatment of Buerger's disease: a review. Int J Low Extrem Wounds 2006; 5 (2): 89-95

13. Shionoya S. Diagnostic criteria of Buerger's disease. Int J Cardiol. 1998; 66 (1); 243-245

14. Olin JW. Thromboangiitis obliterans (Buerger's disease). The New England Journal of Medicine 2000; 343 (12): 864-869

15. Cattaneo M; Aspirin and ClopidogrelArteriosclerosis, thrombosis, and vascular biology, 2004-Am Heart Asso

16. Kostka-Trąbka, E., et al. "Pentoxyfilline (Trental) in treatment of arteriosclerosis obliterans.” Zbl Pharm 122 (1983): 763-765.

17. Boyd S.T, Fremming BA. Rimonabant-a selective CB1 antagonist. Ann Pharmacother. 2005; 39 (4): 684-690

18. Dawson DL, Cutler BS, Hiatt WR, Hobson RW, Martin JD, Bortey EB, Forbes WP, Strandness Jr ; A comparison of cilostazol and pentoxifylline for treating intermittent claudication American J of Med. 2000;109 (2) : 523-530

19. Sasajima T, Kubo Y, Inaba M, Goh K, Azuma N. Role of infrainguinal bypass in Buerger's disease: an eighteen-year experience. Eur J Vasc Endovasc Surg. 1997; 13 (2): 186-192

20. Bozkurt K, Besirli K, Koksal C et al. Surgical treatment of Buerger's disease. Vascular 2004; 12: 192-197

21. Chander J, Singh L, Lal P, Jain A, Lal P, Ramteke VK. Retroperitoneoscopic lumbar sympathectomy for buerger's disease: a novel technique. JSLS. 2004; 8 (3): 291-296

22. Nesargikar PN, Ajit MK, Eyers PS, Nichols BJ, Chester JF. Lumbar chemical sympathectomy in peripheral vascular disease: does it still have a role?. International Journal of Surgery 2009; 7 (2): 145-149

23. Fiessinger JN, Schäfer M. Trial of iloprost versus aspirin treatment for critical limb ischaemia of thromboangiitis obliterans. The Lancet 1990 335 (8689): 555-557

24. Verstraete M. Oral iloprost in the treatment of thromboangiitis obliterans (Buerger's disease): a double-blind, randomised, placebo-controlled trial. Eur J Vasc Endovasc Surg. 1998; 15 (4): 300-307

25. Bozkurt K, Cengiz K, Arslan C et al. A Stable prostacyclin analogue (iloprost) in the treatment of Buerger's disease: a prospective analysis of 150 patients. Ann Thorac and Cardiovasc Surg. 2013; 19 (2): 120-150
26. Wei X, Yang X, Han ZP, Qu FF, Shao L, Shi YF. Mesenchymal stem cells: a new trend for cell therapy. Acta Pharmacol Sin. 2013; 34: 747-754

27. Pittenger MF, Mackay AM, Beck SC, Jaiswal RK, Douglas R, Mosca, JD, Moorman MA, Simonetti DW, Craig S,Marshak DR. Multilineage potential of adult human mesenchymal stem cells. Science 1999; 284: 143-147

28. Figueroa FF, Carri'on F, Villanueva S, Khoury M. Mesenchymal Stem Cell treatment for autoimmune diseases: a critical review. Biol Res. 2012; 45: 269-277

29. Ghannam S, Bouffi C, Djouad F, Jorgensen C, Noel D. Immunosuppression by mesenchymal stem cells: Mechanisms and clinical applications. Stem Cell Res Ther. 2010; 1 (1): 2

30. Shabbir A, Zisa D, Suzuki G, Lee T. Heart failure therapy mediated by the trophic activities of bone marrow mesenchymal stem cells: A noninvasive therapeutic regimen. Am. J. Physiol. Heart Circ. Physiol. 2009; 296: 1888- 1897

31. Phadnis SM, Joglekar MV, Dalvi MP, Muthyala S, Nair PD, Ghaskadbi SM, Bhonde RR, Hardikar AA. Human bone marrow-derived mesenchymal cells differentiate and mature into endocrine pancreatic lineage in vivo. Cytotherapy 2011; 13: 279-293

32. Suzuki M, McHugh J, Tork C, Shelley B, Hayes A, Bellantuono I, Aebischer P, Svendsen CN. Direct muscle delivery of GDNF with human mesenchymal stem cells improves motor neuron survival and function in a rat model of familial ALS. Mol. Ther. 2008; 16: 2002-2010

33. Kang BJ, Kim H, Lee SK, Kim J, Shen Y, Jung S, Kang KS, Im SG, Lee SY, Choi M et al. Umbilical-cord-blood-derived mesenchymal stem cells seeded onto fibronectin-immobilized polycaprolactone nanofiber improve cardiac function. Acta Biomater. 2014; 10: 3007-3017

34. Friedenstein AJ, Gorskaja JF, Kulagina NN. Fibroblast precursors in normal and irradiated mouse hematopoietic organs. Exp. Hematol. 1976; 4: 267-274

35. Zuk PA, Zhu M, Mizuno H, Huang J, Futrell JW, Katz AJ, Benhaim P, Lorenz HP, Hedrick MH. Multilineage cells from human adipose tissue: Implications for cell-based therapies. Tissue Eng. 2001; 7: 211-228

36. Cai J, Li W, Su H, Qin D, Yang J, Zhu F, Xu J, He W, Guo X, Labuda K et al. Generation of human induced pluripotent stem cells from umbilical cord matrix and amniotic membrane mesenchymal cells. J. Biol. Chem. 2010; 285: 11227-11234

37. Schuring AN, Schulte N, Kelsch R, Ropke A, Kiesel L,Gotte M. Characterization of endometrial mesenchymal stem-like cells obtained by endometrial biopsy during routine diagnostics. Fertil Steril. 2011; 95 (1): 423-426

38. Huang GT, Gronthos S, Shi S. Mesenchymal stem cells derived from dental tissues vs. those from other sources: their biology and role in regenerative medicine. J. Dent. Res. 2009; 88: 792-806

39. Romanov YA, Svintsitskaya VA, Smirnov VN. Searching for alternative sources of postnatal human mesenchymal stem cells: Candidate MSClike cells from umbilical cord. Stem Cells 2003; 21: 105-110

40. Wang HS, Hung SC, Peng ST, Chen CC. Mesenchymal stem cells in the Wharton's jelly of the human umbilical cord. Stem Cells 2004; 22: $1330-1337$

41. Kern S, Eichler H, Stoeve J, Kluter H, Bieback K. Comparative analysis of mesenchymal stem cells from bone marrow, umbilical cord blood, or adipose tissue. Stem Cells 2006; 24: 1294-1301

42. Noel D, Caton D, Roche S, Bony C, Lehmann S, Casteilla L, Jorgensen C, Cousin B. Cell specific differences between human adipose-derived and mesenchymal- stromal cells despite similar differentiation potentials. Exp. Cell Res. 2008; 314: 1575-1584

43. Jurgens WJ, Oedayrajsingh-Varma MJ, Helder MN, Zandiehdoulabi B, Schouten TE, Kuik DJ, Ritt MJ, van Milligen FJ. Effect of tissue-harvesting site on yield of stem cells derived from adipose tissue: Implications for cell-based therapies. Cell Tissue Res. 2008; 332: 415-426

44. Wilke MM, Nydam DV, Nixon AJ. Enhanced early chondrogenesis in articular defects following arthroscopic mesenchymal stem cell implantation in an equine model. J. Orthop. Res. 2007; 25: 913-925

45. Zhang HN, Li L, Leng P, Wang YZ, Lv CY. Uninduced adipose-derived stem cells repair the defect of full-thickness hyaline cartilage. Chin. J. Traumatol. 2009; 12: 92-97 
46. Perin EC, Sanz-Ruiz R, Sánchez PL, Lasso J, Pérez-Cano R, Alonso-Farto JC, Pérez-David E, Fernández-Santos ME, Serruys PW, Duckers HJ, Kastrup J, Chamuleau S, Zheng Y, Silva GV, Willerson JT, Fernández-Avilés F. Adipose-derived regenerative cells in patients with ischemic cardiomyopathy. Am Heart J. 2014; 168 (1): 88-95

47. Liew A, O’Brien T. Therapeutic potential for mesenchymal stem cell transplantation in critical limb ischemia. Stem Cell Res Ther. 2012; 3 (4): 28

48. Kim SW, Han H, Chae GT, Lee SH, Bo S, Yoon JH, Lee YS, Lee KS, Park HK, Kang KS. Successful stem cell therapy using umbilical cord blood-derived multipotent stem cells for Buerger's disease and ischemic limb disease animal model. Stem Cells 2006; 24: 1620-1626

49. Dash NR, Dash SN, Routray P, Mohapatra S, Mohapatra PC. Targeting nonhealing ulcers of lower extremity in human through autologous bone marrow-derived mesenchymal stem cells. Rejuvenation Res. 2009; 12: 359-366

50. Lee HC, An SG, Lee HW, Park JS, Cha KS, Hong TJ, Park JH, Lee SY, Kim SP, Kim YD, Chung SW, Bae YC, Shin YB, Kim JI, Jung JS. Safety and effect of adipose tissue-derived stem cell implantation in patients with critical limb ischemia. Circ J 2012; 76 (7):1750-1760

51. Guiducci S, Porta F, Saccardi R, Guidi S, Ibba-Manneschi L, Manetti M, Mazzanti B, Dal Pozzo S, Milia AF, Bellando-Randone S, Miniati I,
Fiori G, Fontana R, Amanzi L, Braschi F, Bosi A, Matucci-Cerinic M. Autologous mesenchymal stem cells foster revascularization of ischemic limbs in systemic sclerosis: a case report. Ann Intern Med 2010; 153: $650-654$

52. Lasala GP, Silva JA, Gardner PA, Minguell JJ. Combination stem cell therapy for the treatment of severe limb ischemia: safety and efficacy analysis. Angiology 2010; 61: 551-556

53. Lasala GP, Silva JA, Minguell JJ. Therapeutic angiogenesis in patients with severe limb ischemia by transplantation of a combination stem cell product. J Thorac Cardiovasc Surg 2012; 144 (2): 377-382

54. Stempeutics announces clinical trial outcome of India's first stem cell product stempeucel-[http://www.stempeutics.com/html/Article\%201.]

55. Jayaraman KS. India's first stem cell based drug.Nature India 2016; doi:10.1038/nindia.2016.61

56. Pluristem Therapeutics, Inc. (PSTI)-[http://www.pluristem.com/ CPY155053[1].pdf]

57. http://www.ema.europa.eu/ema/index.jsp?curl=pages/medicines/ human/orphans/2017/05/human_orphan_001946.jsp\&mid=WC0b01ac058001d12b 